\title{
Calcium-dependent upregulation of E4BP4 expression correlates with glucocorticoid-evoked apoptosis of human leukemic CEM cells
}

\author{
Saul J. Priceman ${ }^{\text {a, }}$, Jonathan D. Kirzner a, Laura J. Nary ${ }^{\text {a }}$, Devin Morris ${ }^{\text {a }}$, \\ Deepa B. Shankar ${ }^{b}$, Kathleen M. Sakamoto ${ }^{b}$, Rheem D. Medh ${ }^{\mathrm{a}, *}$ \\ a Department of Biology, California State University at Northridge, Northridge, CA 91330-8303, USA \\ ${ }^{\mathrm{b}}$ Division of Hematology-Oncology, Mattel Children's Hospital, Department of Pathology and Laboratory Medicine, \\ David Geffen School of Medicine, University of California at Los Angeles, Los Angeles, CA 90095-1752, USA
}

Received 7 March 2006

Available online 5 April 2006

\begin{abstract}
Glucocorticoid (GC)-evoked apoptosis of T-lymphoid cells is preceded by increases in the intracellular $\mathrm{Ca}^{2+}$ concentration $\left(\left[\mathrm{Ca}^{2+}\right]_{\mathrm{i}}\right)$, which may contribute to apoptosis. This report demonstrates that GC-mediated upregulation of the bZIP transcriptional repressor gene, E4BP4, is dependent on $\left[\mathrm{Ca}^{2+}\right]_{\mathrm{i}}$ levels, and correlates with GC-evoked apoptosis of GC-sensitive CEM-C7-14 cells. Calcium chelators EGTA and BAPTA reduced $\left[\mathrm{Ca}^{2+}\right]_{\mathrm{i}}$ levels and protected CEM-C7-14 cells from Dex-evoked E4BP4 upregulation as well as apoptosis. In the GC-resistant sister clone, CEM-C1-15, Dex treatment did not induce $\left[\mathrm{Ca}^{2+}\right]_{\mathrm{i}}$ levels, $E 4 B P 4$ expression or apoptosis, however, the calcium ionophore A23187 restored Dex-evoked E4BP4 upregulation and apoptosis. CEM-C7-14 cells were more sensitive to GC-independent increases in $\left[\mathrm{Ca}^{2+}\right]_{\mathrm{i}}$ levels by thapsigargin, and a corresponding increase in E4BP4 expression and cell death, compared to CEMC1-15 cells, suggesting a direct correlation between $\left[\mathrm{Ca}^{2+}\right]_{\mathrm{i}}$ levels, E4BP4 expression, and apoptosis.
\end{abstract}

(c) 2006 Elsevier Inc. All rights reserved.

Keywords: E4BP4; NFIL3; Apoptosis; Glucocorticoids; Calcium signaling; Gene regulation; Gene repression; T-lymphocytes; Leukemia; CEM cells

Glucocorticoids (GCs) have profound effects on development, metabolism, fluid and electrolyte balance, the stress response, and immune functions. GCs are effective antileukemic agents and kill T-lymphoid cells by inducing classical apoptosis [1]. GCs modulate their actions via binding to specific cytoplasmic GC receptors (GR), which translocate to the nucleus and regulate transcription of target genes [2]. GC-mediated gene regulation is a critical early aspect of GC-evoked apoptosis, and GCs have been shown to up or downregulate distinct sets of genes to evoke T-cell apoptosis $[3,4]$. As is evident from microarray analysis, rather than a single gene, a network of coordinately

\footnotetext{
* Corresponding author. Fax: +1 8186772034.

E-mail address: rheem.medh@csun.edu (R.D. Medh).

${ }^{1}$ Present address: Graduate Program in Molecular and Medical Pharmacology, David Geffen School of Medicine, UCLA, CA 90095, USA.
}

regulated genes influences apoptosis $[5,6]$. Such coordinate changes in gene expression may be facilitated by one or a few regulatory transcription factors.

Microarray analysis of GC-sensitive and -resistant human leukemic lymphoblastoid CEM cells has identified E4BP4 as a gene that is upregulated in response to GCs only in cells susceptible to GC-evoked apoptosis [7]. E4BP4 is a member of the basic region/leucine zipper (bZIP) containing family of transcription factors and shares DNA binding specificities with factors such as c-Jun and CREB [8]. E4BP4 binds to and represses transcription from the consensus sequence of $(\mathrm{G} / \mathrm{A}) \mathrm{T}$ (G/T)A(C/T)GTAA(C/T), unlike other bZIP family proteins, which activate gene transcription [9]. E4BP4 has been suggested to mediate GC-dependent gene repression, an essential contributor of GC-evoked apoptosis [10]. In murine osteoblasts, parathyroid hormone-dependent transcriptional downregulation was shown to be modulated by 
E4BP4 induction [11]. E4BP4 belongs to a highly conserved family of proteins involved in programmed cell death/cell proliferation [12]. Genes closely related to mammalian E4BP4 include genes 8 \& 9 of Xaenopus laevis, ces-2 of Caenorhabditis elegans, and vrille of Drosophila melanogaster, all of which are involved in pro-apoptotic events such as tail resorption, neuronal cell death, and activation of pro-apoptotic signaling molecules $[13,14]$. In contrast to its evolutionarily conserved function as a promoter of cell death, E4BP4 has been suggested to protect growth factor-dependent B-lymphocytes from apoptosis caused by interleukin-3 deprivation [15]. E4BP4 has been shown to regulate motoneuron growth and survival during neuronal development [16]. Upregulation of E4BP4 expression is associated with growth repression and apoptosis in response to tumor suppressors such as phosphatase and tensin homolog (PTEN) [17]. Studies presented here suggest a pro-apoptotic role for E4BP4 in GC-evoked T-lymphoblastic cell death.

Increase in $\left[\mathrm{Ca}^{2+}\right]_{\mathrm{i}}$ is an early and essential event during $\mathrm{T}$ and $\mathrm{B}$ cell activation, and is accompanied by regulation of transcription factors and alterations in gene expression that eventually modulate immune function, cell proliferation, differentiation, and death [18]. In thymocytes and T-lymphoblastoid cells, an increase in intracellular calcium $\left(\left[\mathrm{Ca}^{2+}\right]_{\mathrm{i}}\right)$ levels represents an early biochemical change linked to GC-evoked apoptosis [19]. A correlation between elevation of $\left[\mathrm{Ca}^{2+}\right]_{i}$ and apoptosis has been reported in human leukemic CEM cells [20]. Several mechanisms for calcium-dependent apoptosis have been proposed, including activation of specific $\mathrm{Ca}^{2+}$-dependent nucleases, calmodulin $(\mathrm{CaM})$-mediated activation of calcineurin, and transcriptional changes. In rat vascular smooth muscle cells, an increase in $\left[\mathrm{Ca}^{2+}\right]_{\mathrm{i}}$ upregulates E4BP4 expression [21]. Calcium chelation or specific inhibition of calcium signaling suggests that calcium plays an important role in regulating E4BP4 expression. Since GC-mediated gene repression and increases in $\left[\mathrm{Ca}^{2+}\right]_{\mathrm{i}}$ levels are both critical for GC-evoked apoptosis, we hypothesized that GC-evoked induction of $\left[\mathrm{Ca}^{2+}\right]_{i}$ may upregulate E4BP4 expression and concomitantly activate apoptosis. Data presented here support this hypothesis.

\section{Materials and methods}

Reagents. Dexamethasone (Dex), ethylene glycol tetraacetic acid (EGTA), 2-bis(2-aminophenoxy)-ethane- $N, N, N^{1}, N^{1}$-tetraacetic acid-acetoxymethyl (BAPTA), and thapsigargin (TG) were purchased from EMD Biosciences (Madison, WI). Reagents for RT-PCR, including M-MLV reverse transcriptase, oligo $(\mathrm{dT})_{15}$ primer, $\mathrm{RNasin}{ }^{\circledR}$ Ribonuclease inhibitor, dNTP mix, and Taq DNA polymerase were purchased from Promega Life Sciences (Madison, WI). Calcium Green ${ }^{\mathrm{TM}}-1$ AM, and propidium iodide were purchased from Molecular Probes ${ }^{\mathrm{TM}} /$ Invitrogen (Carlsbad, CA). Other reagent grade chemicals were purchased from Fisher Scientific (Pittsburgh, PA) or Sigma Chemical Co. (St. Louis, MO).

Cell culture. Tissue culture media and components, including fetal bovine serum (FBS) were purchased from Mediatech (Washington, DC). CEM-C7-14 and CEM-C1-15 cells were kindly provided by Dr. E.B. Thompson (UTMB, Galveston, TX), and have been derived from the parental line CCRF-CEM, obtained from a patient with acute lymphoblastic leukemia [22]. Cells were cultured in RPMI 1640 medium supplemented with $5 \% \mathrm{FBS}$ at $37{ }^{\circ} \mathrm{C}$ in a humidified $5 \% \mathrm{CO}_{2}$ incubator, and were maintained in log phase by passaging every 3 days.

Measurement of cell viability. All treatment agents were prepared as 1000 -fold concentrated stock solutions in ethanol. The final concentration of ethanol did not exceed $0.1 \%$ in any experiment, and appropriate controls with ethanol alone were run in parallel. Cells were plated at a density of $1 \times 10^{5}$ cells $/ \mathrm{ml}$ and treated with the appropriate agent for $96 \mathrm{~h}$. Aliquots were removed at $24 \mathrm{~h}$ intervals for cell counts. Viable cells were counted by the trypan blue exclusion method using a hemocytometer.

$\left[\mathrm{Ca}^{2+}\right]_{i}$ measurements. $\left[\mathrm{Ca}^{2+}\right]_{\mathrm{i}}$ levels were measured flow cytometrically [23] at the UCLA Flow Cytometry Core Facility. Cells were treated with the appropriate agents for $24-48 \mathrm{~h}$, washed once in phosphate-buffered saline (PBS), and resuspended in $500 \mu \mathrm{l}$ PBS. The fluorescent dye Calcium Green ${ }^{\mathrm{TM}}$-1 AM (Molecular Probes Cat \# C-3011) was added to a final concentration of $2 \mu \mathrm{M}$, and cells were incubated for a further $60 \mathrm{~min}$ in the $\mathrm{CO}_{2}$ incubator. Five hundred microliters of PBS containing $5 \mu \mathrm{g} / \mathrm{ml}$ propidium iodide was subsequently added to each tube, and fluorescence was measured at $530 \mathrm{~nm}$ (Calcium Green) and $625 \mathrm{~nm}$ (propidium iodide) emission wavelengths using a Becton-Dickinson FACScan Analytical Flow Cytometer.

Evaluation of cell cycle distribution and apoptosis. Cells seeded at a density of $1 \times 10^{5}$ cells $/ \mathrm{ml}$ were treated with $100 \mathrm{nM}$ Dex in the presence or absence of appropriate calcium signaling modulators for $48-72 \mathrm{~h}$. Approximately one million cells were harvested, lysed, and stained sequentially in low and high salt solutions containing propidium iodide to measure DNA content by flow cytometry. To measure apoptosis via TUNEL (terminal deoxynucleotidyl transferase (TdT)-mediated dUTP-Xnick end labeling) assay, cells were fixed in $4 \%$ paraformaldehyde and processed according to the protocol accompanying the kit from Boehringer-Mannheim as described previously [24]. Samples were analyzed flow cytometrically using a FACScan, and the Cell Quest 1.2 software (Becton-Dickinson, Bedford, MA). Data analysis was done using WinMDI 2.8

$R T$-PCR analysis. Cells were treated at a density of $4 \times 10^{5}$ cells $/ \mathrm{ml}$ for $24 \mathrm{~h}$ with the appropriate agent. Approximately $1 \times 10^{7}$ cells were harvested, washed once with chilled PBS, and RNA was extracted using the TRIzol reagent (Invitrogen Life Technologies, La Jolla, CA). Five micrograms of total RNA was reverse transcribed at $42{ }^{\circ} \mathrm{C}$ for $2 \mathrm{~h}$ in the presence of $0.5 \mu \mathrm{g}$ oligo $(\mathrm{dT})_{15}, 1 \mu \mathrm{l}(\sim 200 \mathrm{U}) \mathrm{M}-\mathrm{MLV}$ reverse transcriptase, $0.5 \mathrm{mM}$ dNTP mix, and $100 \mathrm{U}$ RNase inhibitor. A 606 bp E4BP4specific DNA fragment corresponding to nucleotides 709-1314 of the E4BP4 cDNA (GenBank Accession No. X64318) was PCR amplified using 5'-GGCTCTTACACAGCGTCCAT- $3^{\prime}$ and 5'-ATTTGAAG CAGGGGATAGCA-3' ${ }^{\prime}$ oligonucleotides as the sense and antisense primers, respectively. An aliquot of the same reverse transcription product was used to amplify a $914 \mathrm{bp}$ fragment corresponding to $225-1138 \mathrm{bp}$ region of the actin cDNA using $5^{\prime}$-ATTCCTATGTGGGCGACGAG-3' and 5'-CATCTGCTGGAAGGTGGACA-3' sense and antisense primers, respectively.

\section{Results}

\section{Sensitivity to GCS}

As described in the literature [7], and shown in Figure $1_{\mathrm{s}}$ of Supplementary Materials, the CEM sister clones CEMC7-14 and CEM-C1-15 are sensitive and resistant, respectively, to GC-evoked apoptotic cell death.

\section{Correlation of increase in $\left[\mathrm{Ca}^{2+}\right]_{i}$ with apoptosis}

Intracellular $\mathrm{Ca}^{2+}$ levels were monitored flow cytometrically using the fluorescent dye Calcium Green ${ }^{\mathrm{TM}}-1 \mathrm{AM}$, a 
cell permeable dye, which upon binding to calcium, increases the intensity of fluorescence emission at $530 \mathrm{~nm}$ in proportion to the calcium concentration. Cells were simultaneously stained with propidium iodide, a dye that stains DNA if the membrane integrity is compromised, to monitor cell viability. As demonstrated in Fig. 1C, after a $48 \mathrm{~h}$ treatment of CEM-C7-14 cells with $100 \mathrm{nM}$ of the synthetic GC dexamethasone (Dex), 38.1\% cells were viable and had high calcium levels (lower right quadrant). In contrast, in CEM-C1-15 cells, Dex treatment for $48 \mathrm{~h}$ caused only $2.1 \%$ cells were found in the lower right quadrant (panel D). In agreement with the time course of their response to Dex, approximately $19.6 \%$ of CEM-C7-14 cells were non-viable and showed increased propidium iodide staining after $48 \mathrm{~h}$ (upper left quadrant). In contrast, only $4.4 \%$ of CEM-C1-15 cells had increased propidium iodide staining after $48 \mathrm{~h}$ in $100 \mathrm{nM}$ Dex. Ethanol treatment did not significantly affect calcium levels or cell death in either cell type (panels A and B). As shown in Figure 2 2 of Supplementary Material, CEM-C7-14 cells exhibit a doseand time-dependent increase in $\left[\mathrm{Ca}^{2+}\right]_{\mathrm{i}}$ levels. After $24 \mathrm{~h}$ and $48 \mathrm{~h}$ of exposure to $1 \mu \mathrm{M}$ Dex, $14 \%$ and $62 \%$ of cells, respectively, exhibited high $\left[\mathrm{Ca}^{2+}\right]_{\mathrm{i}}$ levels. Our data clearly demonstrate a correlation between cell death and increase in intracellular calcium levels in CEM cells.

Correlation of apoptosis and increases in $\left[\mathrm{Ca}^{2+}\right]_{i}$ with E4BP4 upregulation

The ability of Dex to regulate E4BP4 expression was tested using an RT-PCR assay (Fig. 2). RNA extracted from CEM-C7-14 or CEM-C1-15 cells treated for $24 \mathrm{~h}$ with ethanol or $10 \mathrm{nM}-1 \mu \mathrm{M}$ Dex was reverse transcribed and E4BP4 or actin specific DNA was amplified by PCR
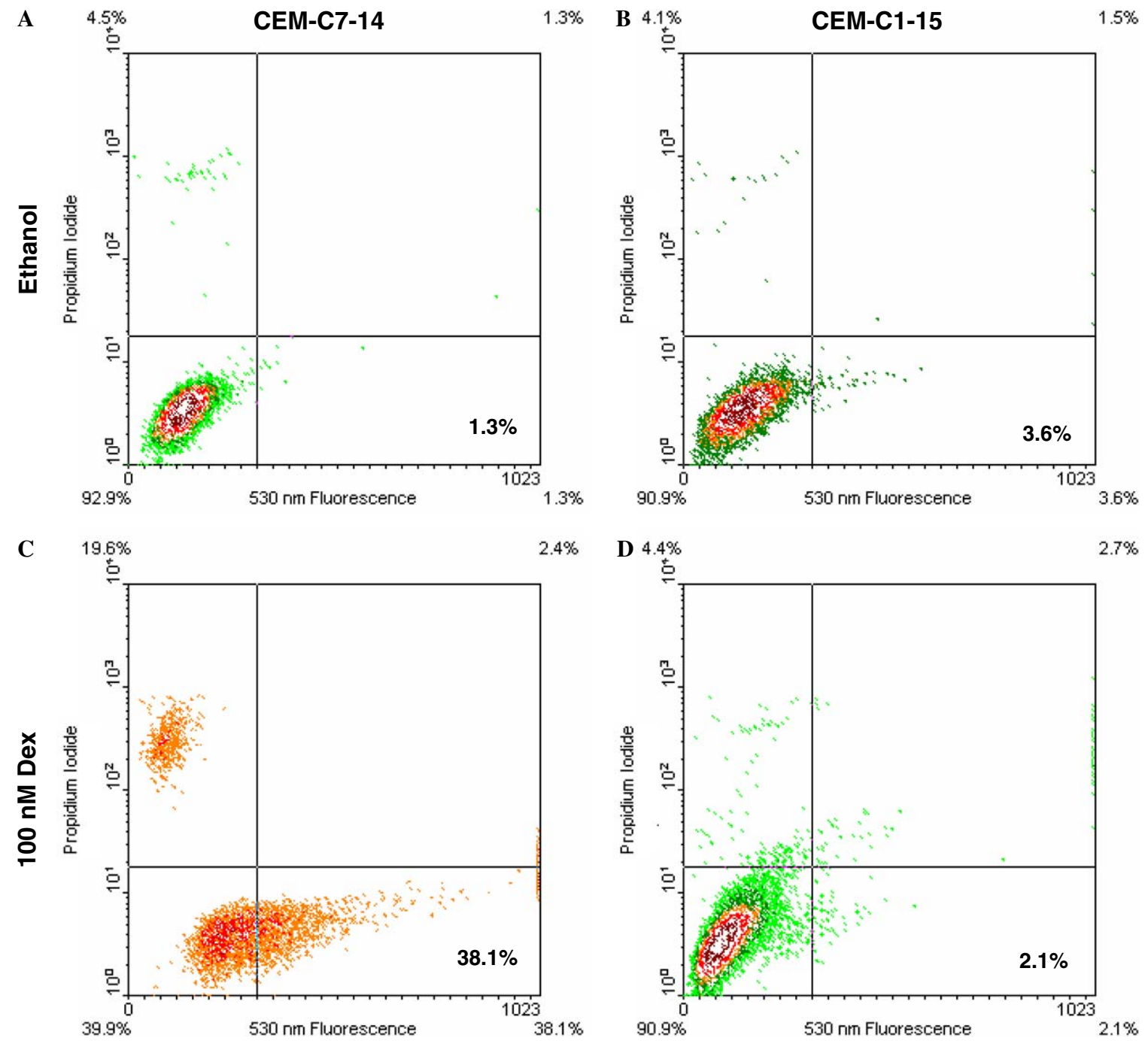

Fig. 1. Increase in intracellular calcium in CEM cells treated with Dex. CEM-C7-14 (A,C) and CEM-C1-15 (B,D) cells were seeded at a density of $2.5 \times 10^{5}$ cells $/ \mathrm{ml}$, treated for $48 \mathrm{~h}$ with ethanol vehicle $(\mathrm{A}, \mathrm{B})$ or $100 \mathrm{nM}$ Dex $(\mathrm{C}, \mathrm{D})$, washed, and resuspended at $1 \times 10^{6}$ cells $/ \mathrm{ml}$. The fluorescent dye Calcium Green ${ }^{\mathrm{TM}}-1 \mathrm{AM}$ was added to cells to a final concentration of $2 \mu \mathrm{M}$, and cells were incubated at $37^{\circ} \mathrm{C}$ for one hour. Propidium iodide dye was added to a final concentration of $2.5 \mu \mathrm{g} / \mathrm{ml}$ to monitor cell viability. Cells were analyzed flow cytometrically for propidium iodide staining (625 $\mathrm{nm}$ ) and for Calcium-Green fluorescence $(530 \mathrm{~nm})$, using a Becton-Dickinson FACScan Flow Cytometer and a WinMDI 2.8 software. 
A
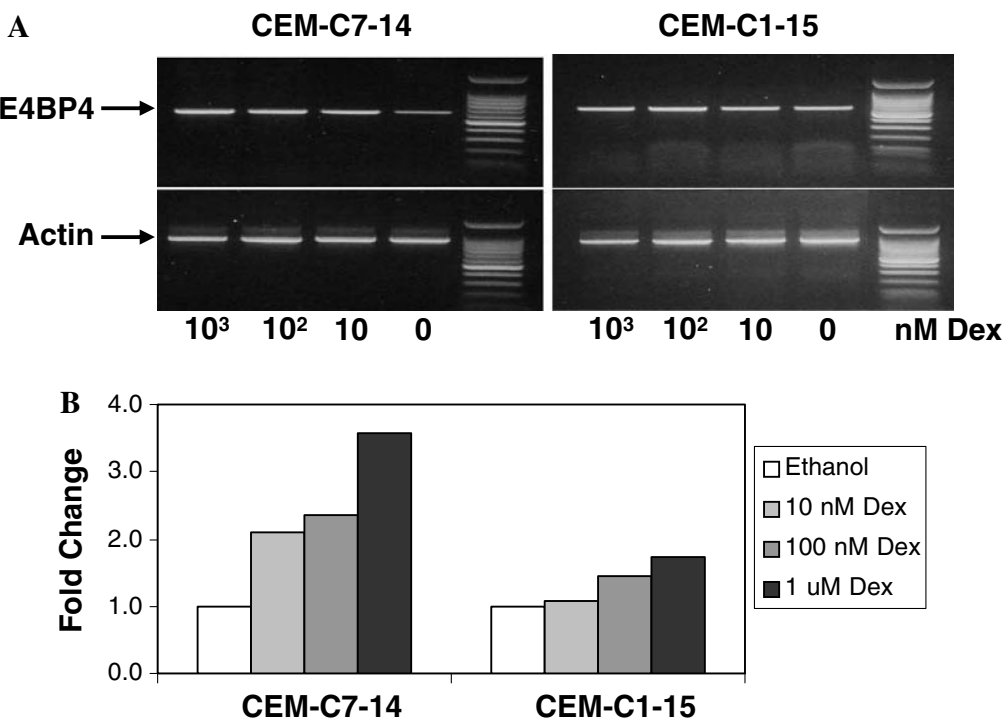

Fig. 2. Upregulation of E4BP4 by Dex correlates with apoptosis. (A) GC-responsive CEM-C7-14 and GC-non-responsive CEM-C1-15 cells were treated for $24 \mathrm{~h}$ at a density of $4 \times 10^{5}$ cells/ml with $0-1 \mu \mathrm{M}$ Dex. Total RNA was extracted, using the TRIzol reagent. Reverse transcription (RT) using $5 \mu \mathrm{g}$ total RNA was performed at $42{ }^{\circ} \mathrm{C}$ using the MMLV reverse transcriptase, dNTP mix, RNase inhibitor, and oligo(dT) $)_{15}$ as a primer. Two microliters of the RT product was subjected to 25 cycles of PCR using the E4BP4 or actin-specific primers indicated in the methods section, to amplify a 606 bp fragment for E4BP4 or a $914 \mathrm{bp}$ fragment for actin. PCR products (10 $\mu \mathrm{l}$ E4BP4, $2 \mu 1$ actin) from variously treated samples were resolved on a $1 \%$ Agarose gel along side a 100 bp DNA ladder. (B) Ethidium bromide stained bands from (A) were densitometrically scanned for band intensity using the ImageJ software, and ratios of E4BP4 to actin band intensities were obtained. Data are represented as fold-change in ratios over ethanol treated controls (0 $\mathrm{nM}$ Dex).

(Fig. 2A). Dex upregulates E4BP4 expression in a dosedependent manner in CEM-C7-14 cells, while minimally upregulating expression in CEM-C1-15 cells. In CEMC7-14 cells, $10 \mathrm{nM}$ Dex was sufficient to evoke a 2-fold increase in E4BP4 expression over basal (ethanol treated) levels, while the same concentration failed to evoke a response in CEM-C1-15 cells. In CEM-C7-14 cells, $1 \mu \mathrm{M}$ Dex evoked a 3.5-fold increase, while in CEM-C1-15 cells the increase was approximately 1.7-fold (Fig. 2B).

\section{Protection of CEM-C7-14 cells from GC-evoked apoptosis by calcium chelators}

To test the hypothesis that increases in $\left[\mathrm{Ca}^{2+}\right]_{\mathrm{i}}$ mediate an increase in E4BP4 expression and subsequent apoptosis, the ability of intra- and extracellular calcium chelators to protect CEM-C7-14 cells from Dex-evoked cell death was evaluated. The intracellular calcium chelator 2-bis(2aminophenoxy)-ethane- $N, N, N^{1}, N^{1}$-tetraacetic acid-acetoxymethyl (BAPTA)-AM and the extracellular calcium chelator, ethylene glycol tetra acetic acid (EGTA) at concentrations above $10 \mu \mathrm{M}$ BAPTA or $200 \mu \mathrm{M}$ EGTA are toxic and compromise cell viability (data not shown). Lower concentrations of these chelators themselves have no effect on cell viability, but significantly protect CEMC7-14 cells from cell death evoked by $100 \mathrm{nM}$ Dex. Four days after treatment with $100 \mathrm{nM}$ Dex cell viability had reduced to $8 \%$ of ethanol treated controls. In the presence of $1 \mu \mathrm{M}$ BAPTA or $20 \mu \mathrm{M}$ EGTA, the Dex-evoked death was reduced, with viable cell numbers being $23 \%$ and $28 \%$ of ethanol treated or BAPTA or EGTA alone treated controls (Fig. 3A). These data support our hypothesis that increases in $\left[\mathrm{Ca}^{2+}\right]_{\mathrm{i}}$ mediate $\mathrm{GC}$-evoked apoptosis of CEM-C7-14 cells. To confirm that BAPTA and EGTA were actually reducing $\left[\mathrm{Ca}^{2+}\right]_{\mathrm{i}}$ levels, flow cytometric measurements of $\left[\mathrm{Ca}^{2+}\right]_{\mathrm{i}}$ levels were made using Calcium Green $^{\mathrm{TM}}{ }_{-1}$ AM. In correlation with the protection from Dex-evoked apoptosis conferred by BAPTA and EGTA, these chelators were able to modestly reduce $\left[\mathrm{Ca}^{2+}\right]_{\mathrm{i}}$ levels, as shown for EGTA in Fig. 4. CEM-C7-14 cells treated with ethanol (panel A), $100 \mathrm{nM}$ Dex (panel B) or $1 \mu \mathrm{M}$ Dex (panel C) exhibited $4.4 \%, 16.4 \%$, and $35 \%$ cells with high $\left[\mathrm{Ca}^{2+}\right]_{\mathrm{i}}$ levels, respectively (in the lower right quadrant). In the presence of $20 \mu \mathrm{M}$ EGTA, these numbers were reduced to $2 \%, 12.4 \%$, and $23.1 \%$ respectively (panels D-F). Similar results were obtained for BAPTA (data not shown).

\section{Sensitization of CEM-C1-15 cells to GC-evoked apoptosis} by the calcium ionophore A23187

Since the resistance of CEM-C1-15 to Dex correlates with an inability to induce $\left[\mathrm{Ca}^{2+}\right]_{i}$ levels, the effect of elevating $\left[\mathrm{Ca}^{2+}\right]_{\mathrm{i}}$ on cell viability was tested. Neither $100 \mathrm{nM}$ Dex nor $150 \mathrm{nM}$ A23187 significantly affected cell viability. However, combined treatment with Dex and A23187 reduced viable cell number to $14 \%$ of individual treatments after $72 \mathrm{~h}$ (Fig. 3B). These data confirm that the GC-resistance of CEM-C1-15 cells is at least partially caused by their inability to increase $\left[\mathrm{Ca}^{2+}\right]_{\mathrm{i}}$ levels. In CEM cells, apoptosis is preceded by G1 arrest and accumulation of cells with sub-G1 DNA content. To test the ability of 

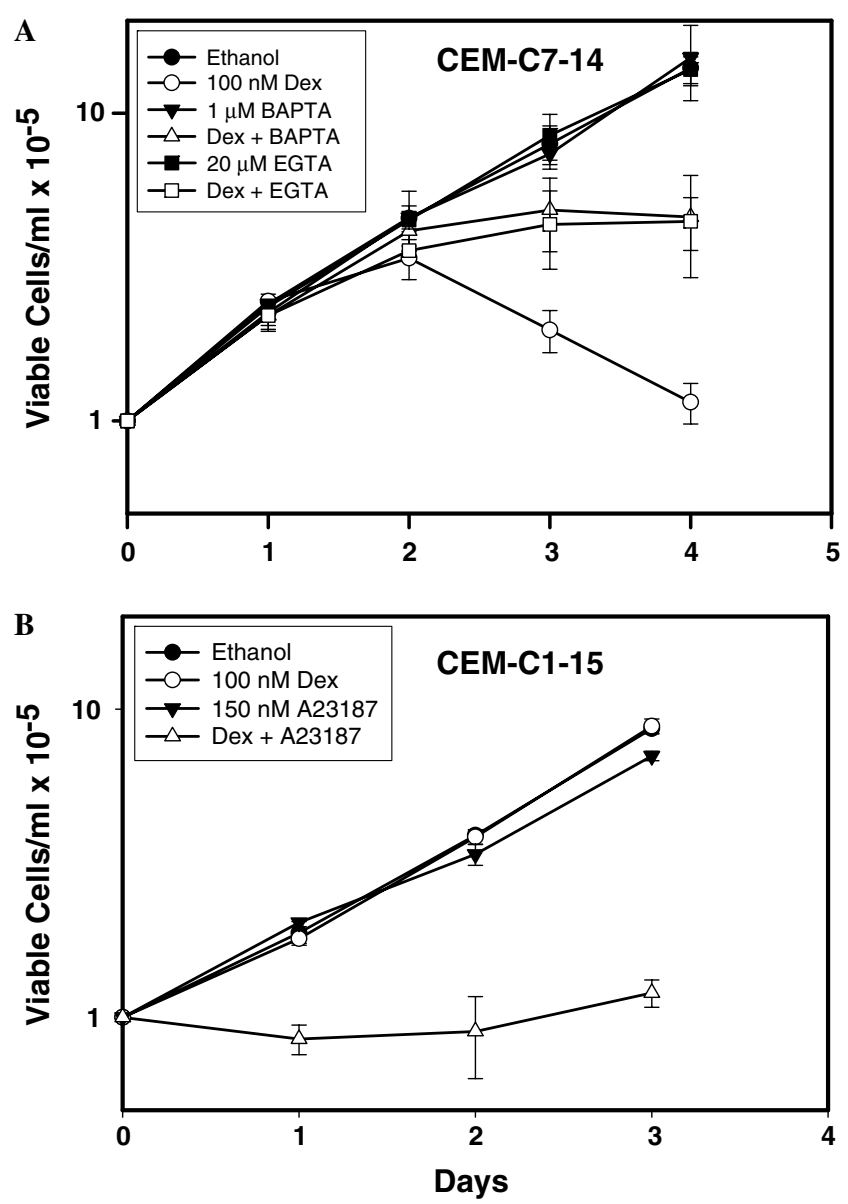

Fig. 3. Modulators of $\left[\mathrm{Ca}^{2+}\right]_{\mathrm{i}}$ levels influence Dex-evoked death of CEM cells. (A) Calcium chelators protect CEM-C7-14 cells from Dex-evoked apoptosis: CEM-C7-14 cells plated at a final density of $1 \times 10^{5}$ cells $/ \mathrm{ml}$ were treated for $0-4$ days with either ethanol (closed symbols) or $100 \mathrm{nM}$ Dex (open symbols), in the presence of ethanol vehicle (circles) $20 \mu \mathrm{M}$ EGTA (squares), or $1 \mu \mathrm{M}$ BAPTA-AM (triangles). Cells were incubated at $37 \mathrm{C}$ in a humidified $5 \% \mathrm{CO}_{2}$ incubator and trypan blue excluding viable cells were counted at $24 \mathrm{~h}$ intervals for a total of $96 \mathrm{~h}$. Each point represents a mean $\pm \mathrm{SD}$ of quadruplicate treatments from two independent experiments. (B) Calcium ionophore sensitizes CEM-C1-15 cells to Dex-evoked death: CEM-C1-15 cells plated at a final density of $1 \times 10^{5}$ cells $/ \mathrm{ml}$ were treated for $0-3$ days with ethanol (closed symbols) or $100 \mathrm{nM}$ Dex (open symbols), in the presence of ethanol vehicle (circles) or $150 \mathrm{nM}$ A23187 (triangles). Cells were incubated at $37 \mathrm{C}$ in a humidified $5 \% \mathrm{CO}_{2}$ incubator and trypan blue excluding viable cells were counted at $24 \mathrm{~h}$ intervals for a total of $72 \mathrm{~h}$. Each point represents a mean \pm SD of quadruplicate treatments from two independent experiments.

A23187 to sensitize CEM-C1-15 cells to GC-evoked apoptosis, cells treated with ethanol alone, $100 \mathrm{nM}$ Dex, $150 \mathrm{nM}$ A23187, or both agents together were stained with propidium iodide and subjected to cell cycle analysis by flow cytometry (Figure 3 s, Supplementary Material). After $48 \mathrm{~h}$ of treatment, $1.4 \%, 2 \%$, and $8.8 \%$ of cells treated with ethanol, $100 \mathrm{nM}$ Dex, and $150 \mathrm{nM}$ A23187 respectively, had a sub-G1 DNA content. Combined treatment with $100 \mathrm{nM}$ Dex and $150 \mathrm{nM}$ A23187 caused 32\% of cells to accumulate in sub G1, suggesting an apoptotic mechanism of cell death.
Modulation of E4BP4 expression by manipulating $\left[\mathrm{Ca}^{2+}\right]_{i}$ levels

To determine whether E4BP4 expression is dependent on $\left[\mathrm{Ca}^{2+}\right]_{\mathrm{i}}$ levels, CEM-C7-14 cells were treated with ethanol or $100 \mathrm{nM}$ Dex in the absence or presence of either $1 \mu \mathrm{M}$ BAPTA or $20 \mu \mathrm{M}$ EGTA for $24 \mathrm{~h}$. Total RNA was extracted and subjected to RT-PCR analysis to determine the effect of calcium chelation on E4BP4 expression. Both BAPTA and EGTA abolished Dex-evoked upregulation of E4BP4 expression (Fig. 5A), although BAPTA alone evoked a 1.5-fold induction of E4BP4 expression. To determine whether the failure of Dex to upregulate E4BP4 expression in CEM-C1-15 cells was related to the inability of Dex to induce $\left[\mathrm{Ca}^{2+}\right]_{\mathrm{i}}$ levels, CEM-C1-15 cells were treated with Dex in the presence or absence of the calcium ionophore A23187 to raise $\left[\mathrm{Ca}^{2+}\right]_{\mathrm{i}}$ levels. Either Dex or A23187 failed to significantly upregulate E4BP4 expression, however, when combined, these two agents synergistically up regulated E4BP4 expression (Fig. 5B), confirming our hypothesis that GC-mediated induction of E4BP4 expression is modulated via increases in $\left[\mathrm{Ca}^{2+}\right]_{\mathrm{i}}$ levels. Our data support the idea that increases in $\left[\mathrm{Ca}^{2+}\right]_{\mathrm{i}}$ levels may not be sufficient to evoke E4BP4 upregulation but may be necessary to facilitate the GC-evoked cell death.

\section{Effect of thapsigargin on $\left[\mathrm{Ca}^{2+}\right]_{i}$ levels and E4BP4 expression in CEM cells}

Thapsigargin (TG) is a cell permeable sesquiterpene lactone that releases calcium into the cytoplasmic compartment by inhibiting endoplasmic reticular $\mathrm{Ca}^{2+}$-ATPase [25]. It has been shown to induce apoptosis in rat thymocytes [25]. To determine the ability of TG to increase $\left[\mathrm{Ca}^{2+}\right]_{\mathrm{i}}$ and induce cell death, CEM-C7-14 and CEM-C115 cells were treated for $24-72 \mathrm{~h}$ with $1 \mu \mathrm{M}$ TG and cell viability as well as $\left[\mathrm{Ca}^{2+}\right]_{\mathrm{i}}$ levels were monitored by flow cytometry $(40 \mathrm{~h}$ time point shown in Figs. 6A-D) using propidium iodide to monitor loss of membrane integrity, and Calcium Green ${ }^{\mathrm{TM}}-1$ AM to monitor $\left[\mathrm{Ca}^{2+}\right]_{\mathrm{i}}$ levels. The upper left quadrant in Figs. 6A-D represents dead cells that have incorporated propidium iodide, demonstrating a significantly higher cell death in CEM-C7-14 cells (panel C, 45.1\%) when compared to CEM-C1-15 cells (panel D, 13.6\%) in response to TG. CEM-C7-14 cells also demonstrate a significantly greater proportion of cells with high $\left[\mathrm{Ca}^{2+}\right]_{\mathrm{i}}$ levels (lower right quadrant) after TG treatment, with $9.3 \%$ cells falling into the high calcium range compared to only $2.3 \%$ for CEM-C1-15 cells. Since $\left[\mathrm{Ca}^{2+}\right]_{\mathrm{i}}$ levels are in a continuous flux, and flow cytometry measures levels at a particular time, the number of cells with high calcium at any given time are small. By $72 \mathrm{~h}$, a vast majority of viable cells have high $\left[\mathrm{Ca}^{2+}\right]_{\mathrm{i}}$ levels, however, a majority of the CEM-C7-14 cell population was dead (data not shown).

E4BP4 expression was upregulated in a dose-dependent manner in response to TG in both CEM-C7-14 and 

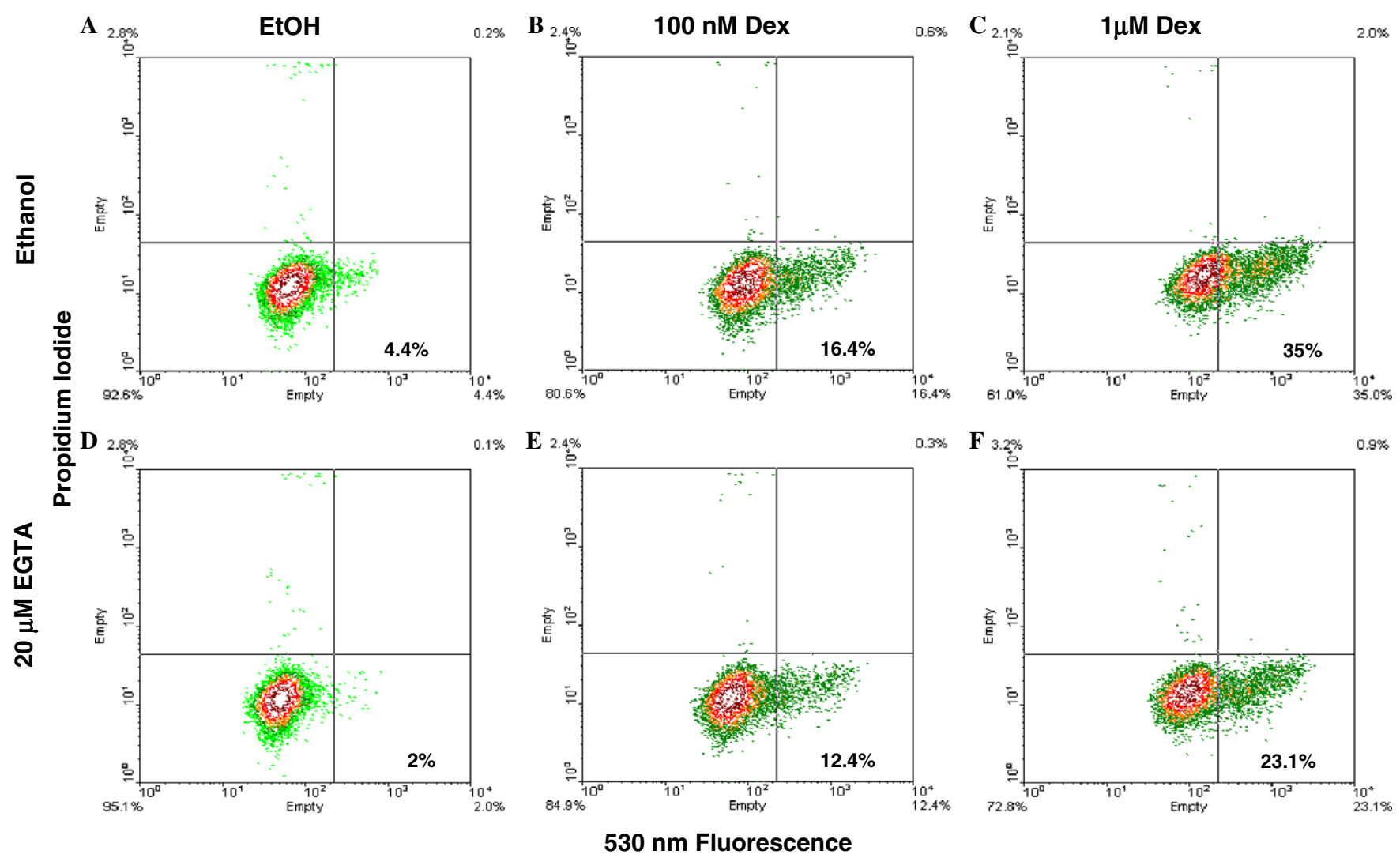

Fig. 4. EGTA suppresses Dex-evoked increase in $\left[\mathrm{Ca}^{2+}\right]_{\mathrm{i}}$ levels in CEM-C7-14 cells. CEM-C7-14 cells were treated with either ethanol, $100 \mathrm{nM}$ or $1 \mu \mathrm{M}$ Dex in the absence (A-C) or presence (D-F) of $20 \mu \mathrm{M}$ EGTA for $48 \mathrm{~h}$, as described for Fig. 2. Cells were harvested and resuspended in PBS containing $2 \mu \mathrm{M}$ Calcium Green ${ }^{\mathrm{TM}}-1 \mathrm{AM}$, and incubated for $1 \mathrm{~h}$. Propidium iodide was added before processing for flow cytometry using a Becton-Dickinson FACScan Flow Cytometer and a WinMDI 2.8 software.

A CEM-C7-14
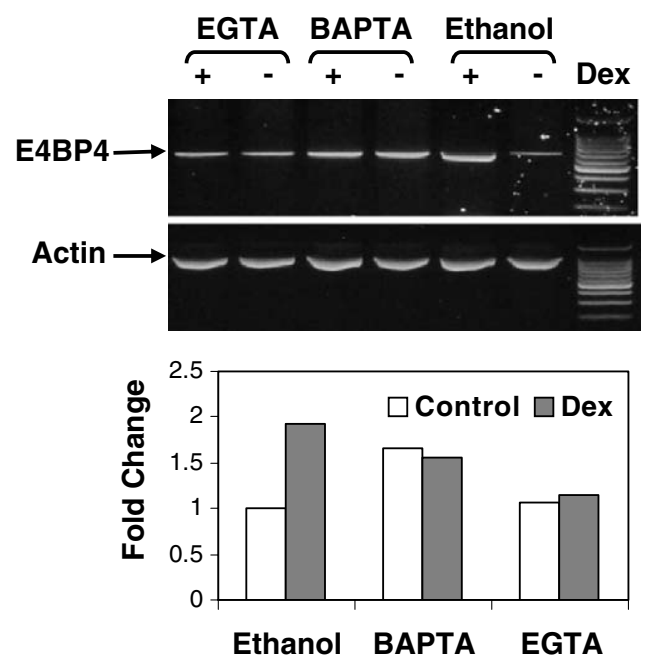

B CEM-C1-15
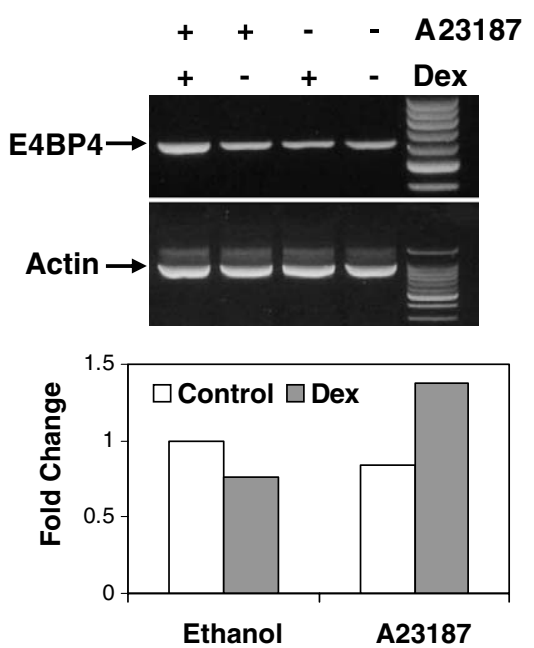

Fig. 5. Modulation of Dex-mediated E4BP4 expression by intracellular calcium. (A) CEM-C7-14 cells at a density of $4 \times 10^{5}$ cells $/ \mathrm{ml}$ were treated for $24 \mathrm{~h}$ with ethanol, $1 \mu \mathrm{M}$ BAPTA or $20 \mu \mathrm{M}$ EGTA in the absence $(-)$ or presence $(+)$ of $100 \mathrm{nM}$ Dex. RNA was extracted and $5 \mu \mathrm{g}$ total RNA was used in a reverse transcription reaction, and subsequent PCR to amplify fragments specific for E4BP4 or actin, as described for Fig. 4. Ratios on E4BP4 to actin band intensities were normalized to ethanol control values to obtain fold-change and are plotted in the lower panel. (B) CEM-C1-15 cells at a density of

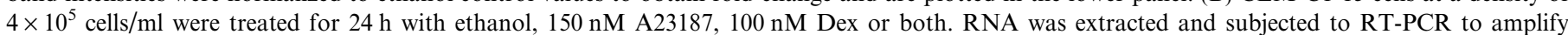
fragments specific for E4BP4 or actin, as described for (A). Fold-change in E4BP4 expression was calculated as in (A) and is plotted in the lower panel. 

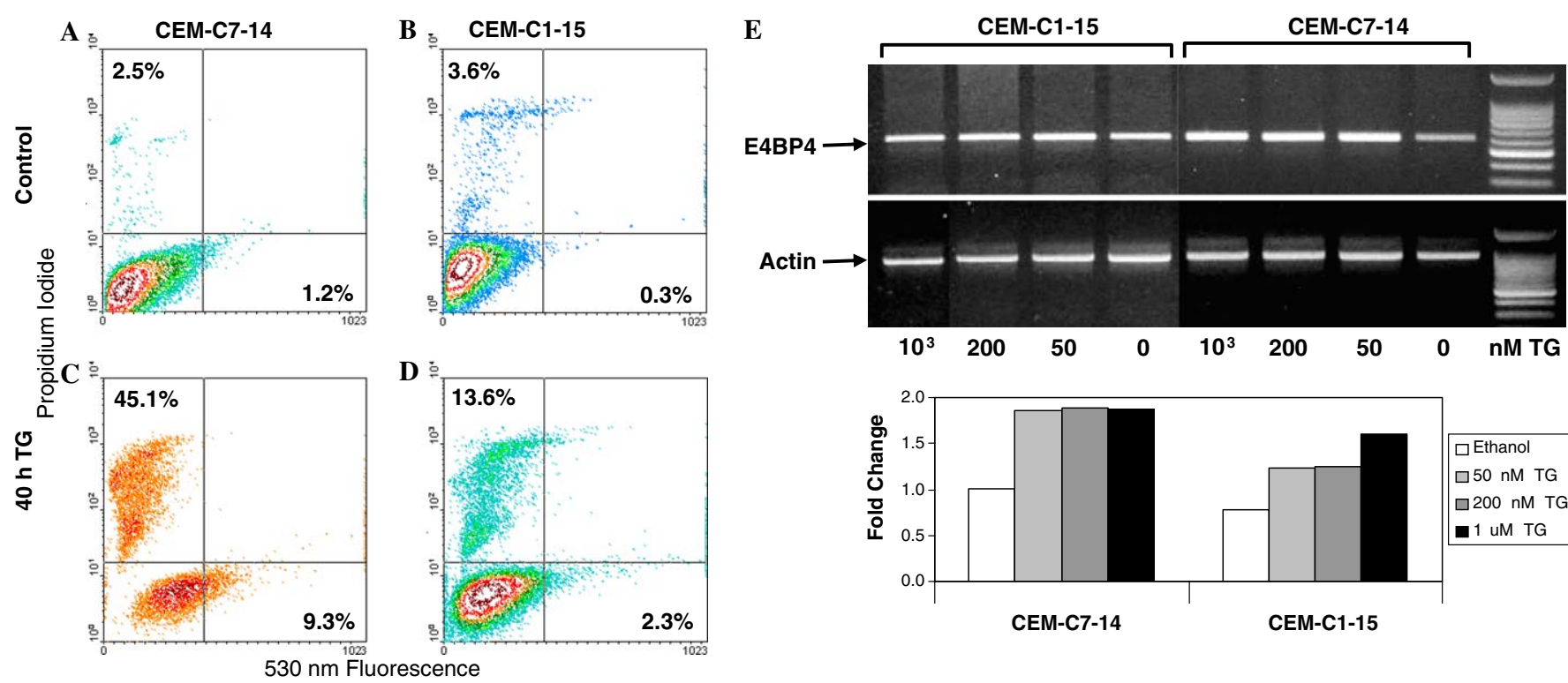

Fig. 6. Increases in intracellular calcium levels and E4BP4 expression by thapsigargin. (A-D) CEM-C7-14 (A,C) or CEM-C1-15 (B,D) cells seeded at a density of $2.5 \times 10^{5}$ cells $/ \mathrm{ml}$ were treated for $40 \mathrm{~h}$ with ethanol (control, A and B) or $1 \mu \mathrm{M}$ thapsigargin (TG, C and D). Cells were washed with phosphate buffered saline, resuspended at approximately $1 \times 10^{6}$ cells $/ \mathrm{ml}$, and incubated for 60 min with $2 \mu \mathrm{M}$ Calcium Green ${ }^{\mathrm{TM}}-1$ AM. Propidium iodide was added to a final concentration of $2.5 \mu \mathrm{g} / \mathrm{ml}$ before cells were analyzed flow cytometrically for fluorescence at $530 \mathrm{~nm}$ (Calcium Green-1) and at $625 \mathrm{~nm}$ (propidium iodide) using a Becton-Dickinson FACScan Flow Cytometer, and WinMDI2.8 software. (E) CEMC7-14 or CEM-C1-15 cells at a final density of $4 \times 10^{5}$ cells $/ \mathrm{ml}$ were treated for $24 \mathrm{~h}$ with $50 \mathrm{nM}, 200 \mathrm{nM}$ or $1 \mu \mathrm{M}$ thapsigargin (TG). Cells were harvested, RNA was extracted and subjected to RT-PCR for E4BP4 and actin as described in Fig. 4. PCR products were resolved on a 1\% agarose gel as in Fig. 4. Ethidium bromide stained bands from the gel were densitometrically scanned for band intensity using the ImageJ software, and ratios of E4BP4 to actin band intensities were plotted in the lower panel. Data are represented as fold-change in ratios over ethanol treated controls (0 nM TG).

CEM-C1-15 cells, however, the effect was much more pronounced in CEM-C7-14 cells (Fig. 6E), with almost 2-fold induction at all concentrations of TG. CEM-C1-15 cells showed only a 1.25 -fold increase up to $200 \mathrm{nM}$ TG, and 1.6-fold induction at $1 \mu \mathrm{M}$ TG. These data correlate with the cell viability and $\left[\mathrm{Ca}^{2+}\right]_{\mathrm{i}}$ levels of the two sister clones in response to TG (Figs. 6A-D), which was also more pronounced in CEM-C7-14 cells. These data confirm our hypothesis that increases in $\left[\mathrm{Ca}^{2+}\right]_{\mathrm{i}}$ levels upregulate E4BP4 expression and contribute to CEM cell apoptosis.

\section{Discussion}

GC-evoked T-lymphocyte apoptosis has been studied extensively, yet the molecular pathway remains unclear. The process requires de novo RNA and protein synthesis, suggesting that gene regulatory changes are crucial for apoptosis induction [26]. GCs regulate a wide array of genes, reflecting their diverse actions on cell physiology. Because of the pleotropic effects of GCs, it has been difficult to correlate GC-evoked apoptosis with specific gene regulatory changes. Studies on individual genes, or microarray analyses have implicated regulatory changes in several genes in GC-evoked T-lymphocyte apoptosis, including downregulation of $c-m y c$, cyclin D3, ornithine decarboxylase $(o d c)$, and upregulation of $G R, c$-jun, dexamethasone-induced gene 2(dig2), FK506 binding protein 51 (FKBP5), Down Syndrome Critical Region 1
(DSCRI), Bim, etc [27-29]. These data suggest that a network of genes, rather than one or a few genes, coordinately regulates apoptosis.

Among the list of genes upregulated in only those CEM cell clones that are susceptible to GC-evoked apoptosis, but not in a CEM clone non-responsive to GCs, is the gene for adenoviral E4 binding protein 4 (E4BP4) [7], an evolutionarily conserved transcriptional repressor belonging to the bZIP family of transcription factors [9]. GR-evoked transcriptional repression has been shown to be important for GC-evoked apoptosis [30]. GC-mediated E4BP4 upregulation has been suggested as a mechanism of gene repression by GCs in murine fibroblasts [10]. Indeed, as demonstrated here, GCs upregulate E4BP4 in human T-lymphoblastic leukemia cells, in correlation with apoptosis. In the two human leukemic CEM sister clones studied here, the synthetic GC Dex upregulated E4BP4 in a dose-dependent manner in only the clone (CEM-C7-14) that was susceptible to Dex-evoked apoptosis. Hence, GC-mediated E4BP4 upregulation may be a key early event that triggers subsequent transcriptional changes, including gene repression, driving a cell towards apoptosis.

Another signature change preceding apoptosis of T-lymphocytes and leukemic $\mathrm{T}$ cells is the increase in $\left[\mathrm{Ca}^{2+}\right]_{\mathrm{i}}$ levels [31,32]. It has been proposed that calcium levels regulate the extent of apoptosis via various mechanisms, including activation of calcium-dependent endonucleases 
and activation of the calcium signaling pathway [19,33,34]. In the CEM model, $\left[\mathrm{Ca}^{2+}\right]_{\mathrm{i}}$ levels were increased only in the GC-susceptible CEM-C7-14 clone, but not in the CEMC1-15 clone, demonstrating a dependence of apoptosis on $\left[\mathrm{Ca}^{2+}\right]_{\mathrm{i}}$ levels. The calcium chelators, BAPTA and EGTA, were able to reduce levels of $\left[\mathrm{Ca}^{2+}\right]_{\mathrm{i}}$ and protect CEM-C714 cells from Dex-evoked apoptosis. In addition, enforced increase in $\left[\mathrm{Ca}^{2+}\right]_{\mathrm{i}}$ levels in CEM-C1-15 cells by A23187 restored sensitivity to Dex-evoked apoptosis. A23187 alone did not kill CEM-C1-15 cells, suggesting that increases in $\left[\mathrm{Ca}^{2+}\right]_{\mathrm{i}}$ levels alone are not sufficient to evoke apoptosis, they merely sensitize the cells to GC-evoked responses.

E4BP4 expression is upregulated in a calcium-dependent manner in rat aortic smooth muscle cells. In this model, inhibition of calcium signaling abrogated calcium-dependent E4BP4 upregulation [21]. In studies described here, GC-mediated E4BP4 upregulation was also shown to be calcium-dependent, and was inhibited by calcium chelators. Data presented here suggest a cause-and-effect relationship between $\mathrm{GC}$-evoked increases in $\left[\mathrm{Ca}^{2+}\right]_{\mathrm{i}}$ levels, E4BP4 upregulation, and CEM cell apoptosis. GC-independent increases in $\left[\mathrm{Ca}^{2+}\right]_{i}$ levels by TG correlated with E4BP4 upregulation and cell death in CEM-C7-14 cells. It was interesting to note that CEM-C1-15 cells were more resistant to TG-evoked increases in $\left[\mathrm{Ca}^{2+}\right]_{\mathrm{i}}$ levels, E4BP4 upregulation, and cell death when compared to CEM-C714 cells, just as has been observed for GC-evoked responses. These results suggest a downstream common pathway between GC and TG to evoke cellular changes resulting in apoptosis.

Within the bZIP family of transcription factors, E4BP4 is closest in homology to those containing a PAR (proline and acidic residue rich) domain, although E4BP4 lacks a PAR domain $[8,12]$. Notably, while PAR containing bZIP factors activate transcription, E4BP4 represses transcription [12]. Other homologous PAR domain lacking bZIP genes include the $C$. elegans ces-2 (cell death selector) gene, which promotes neuronal cell death, the Drosophila vrille gene, which induces apoptosis in embryonic dorsal epidermis, and genes 8 and 9 in $X$. laevis, which contribute to tail resorption $[13,14]$. Based on these homologous genes, one might expect E4BP4 to be pro-apoptotic; however, depending of the cell type and downstream effectors, E4BP4 has been shown to promote cell survival $[15,16]$, induce apoptosis [17], or promote parathyroid hormone-mediated catabolism in osteoblasts [11]. In human B-lymphocytes, E4BP4 is upregulated by IL-3 (hence the alternative name: Nuclear factor regulated by IL3; NFIL3) and promotes survival of IL-3-dependent cells [15]. Similarly, in rat motoneurons, E4BP4 serves as a survival factor, and is expressed at high levels in those neurons that escape natural apoptosis [16]. Interestingly, the C. elegans CES-2 blocks the activity of a survival factor, CES-1, to evoke an apoptotic response [13]. The vertebrate homolog of CES-1, Slug, is upregulated in leukemic B-lymphoblasts by the chimeric oncoprotein, E2A-HLF, which binds to the same consensus sequence as, and is proposed to act similarly to
E4BP4 [35]. These data reveal the opposing effects that ces-2 or E4BP4 have on the downstream survival factors ces-1 or Slug, respectively. E4BP4 actively antagonized the ability of IL-6 to rescue these cells from p53-induced apoptosis, suggesting that E4BP4 was a pro-apoptotic factor [36]. E4BP4 is ubiquitously expressed, however, its expression is shown to be minimal in tumors and transformed cell lines [17]. Upregulation of E4BP4 expression is associated with growth repression and apoptosis in response to tumor suppressors such as phosphatase and tensin homolog (PTEN) [17].

E4BP4 is often referred to in the literature as a survival gene, owing to its role in survival of IL-3-dependent B-lymphocytes. However, it is clear that E4BP4 acts as a pro-apoptotic factor in cancer cells and its upregulation is associated with promotion of apoptosis in some systems.

\section{Acknowledgments}

This work was supported by a NIH MBRS-SCORE Pilot grant (S06-GM048680-10S1) awarded to RDM, the CSUN Office of Graduate Studies, Research and International Programs, and the CSUN College of Science and Mathematics. D.M. was supported through a NASA CSUN/JPL Pair Program fellowship for undergraduate students. We thank Dr. E.B. Thompson (UTMB, Galveston, TX) for kindly providing CEM-C7-14 and CEM-C1-15 cells. We thank the UCLA Flow Cytometry Core Facility for assistance with flow cytometric analyses. The technical assistance provided by undergraduate students Hasmik Hakopian and Yasuko Hirakawa is greatly appreciated.

\section{Appendix A. Supplementary data}

Supplementary data associated with this article can be found, in the online version, at doi:10.1016/j.bbrc. 2006.03.169.

\section{References}

[1] L.A. Smets, G. Salomons, J. van den Berg, Glucocorticoid induced apoptosis in leukemia, Adv. Exp. Med. Biol. 457 (1999) 607-614.

[2] E.P. Slater, T. Anderson, P. Cattini, R. Isaacs, M.J. Birnbaum, D.G. Gardner, N.L. Eberhardt, J.D. Baxter, Mechanisms of glucocorticoid hormone action, Adv. Exp. Med. Biol. 196 (1986) 67-80.

[3] B.M. Jehn, B.A. Osborne, Gene regulation associated with apoptosis, Crit. Rev. Eukaryot. Gene Expr. 7 (1997) 179-193.

[4] R.B. Evans-Storms, J.A. Cidlowski, Regulation of apoptosis by steroid hormones, J. Steroid Biochem. Mol. Biol. 53 (1995) 1-8.

[5] E.B. Thompson, M.S. Webb, A.L. Miller, Y. Fofanov, B.H. Johnson, Identification of genes leading to glucocorticoid-induced leukemic cell death, Lipids 39 (2004) 821-825.

[6] N.L. Yoshida, T. Miyashita, M. U, M. Yamada, J.C. Reed, Y. Sugita, T. Oshida, Analysis of gene expression patterns during glucocorticoid-induced apoptosis using oligonucleotide arrays, Biochem. Biophys. Res. Commun. 293 (2002) 1254-1261.

[7] R.D. Medh, M.S. Webb, A.L. Miller, B.H. Johnson, Y. Fofanov, T. Li, T.G. Wood, B.A. Luxon, E.B. Thompson, Gene expression profile of human lymphoid CEM cells sensitive and resistant to glucocorticoid-evoked apoptosis, Genomics 81 (2003) 543-555. 
[8] W.J. Chen, K.S. Lewis, G. Chandra, J.P. Cogswell, S.W. Stinnett, S.H. Kadwell, J.G. Gray, Characterization of human E4BP4, a phosphorylated bZIP factor, Biochim. Biophys. Acta 1264 (1995) 388-396.

[9] I.G. Cowell, H.C. Hurst, Transcriptional repression by the human bZIP factor E4BP4: definition of a minimal repression domain, Nucleic Acids Res. 22 (1994) 59-65.

[10] A.D. Wallace, T.T. Wheeler, D.A. Young, Inducibility of E4BP4 suggests a novel mechanism of negative gene regulation by glucocorticoids, Biochem. Biophys. Res. Commun. 232 (1997) 403-406.

[11] I.C. Ozkurt, S. Tetradis, Parathyroid hormone-induced E4BP4/ NFIL3 down-regulates transcription in osteoblasts, J. Biol. Chem. 278 (2003) 26803-26809.

[12] I.G. Cowell, E4BP4/NFIL3, a PAR-related bZIP factor with many roles, Bioessays 24 (2002) 1023-1029.

[13] S. Szuplewski, B. Kottler, R. Terracol, The Drosophila bZIP transcription factor Vrille is involved in hair and cell growth, Development 130 (2003) 3651-3662.

[14] M.M. Metzstein, M.O. Hengartner, N. Tsung, R.E. Ellis, H.R. Horvitz, Transcriptional regulator of programmed cell death encoded by Caenorhabditis elegans gene ces-2, Nature 382 (1996) 545-547.

[15] S. Ikushima, T. Inukai, T. Inaba, S.D. Nimer, J.L. Cleveland, A.T. Look, Pivotal role for the NFIL3/E4BP4 transcription factor in interleukin 3-mediated survival of pro-B lymphocytes, Proc. Natl. Acad. Sci. USA 94 (1997) 2609-2614.

[16] D. Junghans, S. Chauvet, E. Buhler, K. Dudley, T. Sykes, C.E. Henderson, The CES-2-related transcription factor E4BP4 is an intrinsic regulator of motoneuron growth and survival, Development 131 (2004) 4425-4434.

[17] M. Unoki, Y. Nakamura, Growth-suppressive effects of BPOZ and EGR2, two genes involved in the PTEN signaling pathway, Oncogene 20 (2001) 4457-4465.

[18] R.S. Lewis, Calcium signaling mechanisms in T lymphocytes, Annu. Rev. Immunol. 19 (2001) 497-521.

[19] X. Bian, F.M. Hughes Jr., Y. Huang, J.A. Cidlowski, J.W. Putney Jr., Roles of cytoplasmic $\mathrm{Ca}^{2+}$ and intracellular $\mathrm{Ca}^{2+}$ stores in induction and suppression of apoptosis in S49 cells, Am. J. Physiol. 272 (1997) C1241-C1249

[20] F. Adebodun, J.F. Post, Role of intracellular free $\mathrm{Ca}(\mathrm{II})$ and $\mathrm{Zn}(\mathrm{II})$ in dexamethasone-induced apoptosis and dexamethasone resistance in human leukemic CEM cell lines, J. Cell. Physiol. 163 (1995) $80-86$.

[21] Y. Nishimura, T. Tanaka, Calcium-dependent activation of nuclear factor regulated by interleukin 3/adenovirus E4 promoter-binding protein gene expression by calcineurin/nuclear factor of activated $\mathrm{T}$ cells and calcium/calmodulin-dependent protein kinase signaling, J. Biol. Chem. 276 (2001) 19921-19928.

[22] G.E. Foley, H. Lazarus, S. Farber, B.G. Uzman, B.A. Boone, R.E. McCarthy, Continuous culture of human lymphoblasts from peripheral blood of a child with acute leukemia, Cancer 18 (1965) 522-529.
[23] S.W. Burchiel, B.S. Edwards, F.W. Kuckuck, F.T. Lauer, E.R. Prossnitz, J.T. Ransom, L.A. Sklar, Analysis of free intracellular calcium by flow cytometry: multiparameter and pharmacologic applications, Methods 21 (2000) 221-230.

[24] R.D. Medh, A. Wang, F. Zhou, E.B. Thompson, Constitutive expression of ectopic c-Myc delays glucocorticoid-evoked apoptosis of human leukemic CEM-C7 cells, Oncogene 20 (2001) 4629-4639.

[25] S. Jiang, S.C. Chow, P. Nicotera, S. Orrenius, Intracellular $\mathrm{Ca}^{2+}$ signals activate apoptosis in thymocytes: studies using the $\mathrm{Ca}(2+)$ ATPase inhibitor thapsigargin, Exp. Cell Res. 212 (1994) 84-92.

[26] A.H. Wyllie, R.G. Morris, A.L. Smith, D. Dunlop, Chromatin cleavage in apoptosis: association with condensed chromatin morphology and dependence on macromolecular synthesis, J. Pathol. 142 (1984) 67-77.

[27] M.S. Webb, A.L. Miller, B.H. Johnson, Y. Fofanov, T. Li, T.G. Wood, E.B. Thompson, Gene networks in glucocorticoid-evoked apoptosis of leukemic cells, J. Steroid Biochem. Mol. Biol. 85 (2003) 183-193.

[28] J. Galon, D. Franchimont, N. Hiroi, G. Frey, A. Boettner, M. Ehrhart-Bornstein, J.J. O'Shea, G.P. Chrousos, S.R. Bornstein, Gene profiling reveals unknown enhancing and suppressive actions of glucocorticoids on immune cells, FASEB J. 16 (2002) 61-71.

[29] C. Ploner, S. Schmidt, E. Presul, K. Renner, K. Schröcksnadel, J. Rainer, S. Riml, R. Kofler, Glucocorticoid-induced apoptosis and glucocorticoid resistance in acute lymphoblastic leukemia, J. Steroid Biochem. Mol. Biol. 93 (2005) 153-160.

[30] A. Helmberg, N. Auphan, C. Caelles, M. Karin, Glucocorticoidinduced apoptosis of human leukemic cells is caused by the repressive function of the glucocorticoid receptor, EMBO J. 14 (1995) 452-460.

[31] D.J. McConkey, P. Nicotera, P. Hartzell, G. Bellomo, A.H. Wyllie, S. Orrenius, Glucocorticoids activate a suicide process in thymocytes through an elevation of cytosolic $\mathrm{Ca}^{2+}$ concentration, Arch. Biochem. Biophys. 269 (1989) 365-370.

[32] C.W. Distelhorst, G. Dubyak, Role of calcium in glucocorticosteroidinduced apoptosis of thymocytes and lymphoma cells: resurrection of old theories by new findings, Blood 91 (1998) 731-734.

[33] N.N. Khodarev, J.D. Ashwell, An inducible lymphocyte nuclear $\mathrm{Ca}^{2+} / \mathrm{Mg}(2+)$-dependent endonuclease associated with apoptosis, J. Immunol. 156 (1996) 922-931.

[34] D.C. Tong, S.M. Buck, B.R. Roberts, J.D. Klein, J.A. Tumlin, Calcineurin phosphatase activity: activation by glucocorticoids and role of intracellular calcium, Transplantation 77 (2004) 259-267.

[35] T. Inukai, A. Inoue, H. Kurosawa, K. Goi, T. Shinjyo, K. Ozawa, M. Mao, T. Inaba, A.T. Look, SLUG, a ces-1-related zinc finger transcription factor gene with antiapoptotic activity, is a downstream target of the E2A-HLF oncoprotein, Mol. Cell 4 (1999) 343-352.

[36] R.A. Altura, T. Inukai, R.A. Ashmun, G.P. Zambetti, M.F. Roussel, A.T. Look, The chimeric E2A-HLF transcription factor abrogates p53-induced apoptosis in myeloid leukemia cells, Blood 92 (1998) $1397-1405$. 